Original articles

if

J. Perinat. Med. 5 (1977) 114

\section{High vasopressin concentrations in human umbilical cord blood - Lack of correlation with stress}

\author{
R. A. Polin, M. K. Husain, L. S. James, A. G. Frantz
}

Division of Perinatal Medicine and the Departments of Pediatrics, Babies Hospital, The Children's Medical and Surgical Center, and the Department of Medicine, Presbyterian Hospital, College of Physicians and Surgeons, Columbia University, New York
Curriculum vitae

RICHARD A. POLIN obtained his doctor of medicine from Temple University Medical School in Philadelphia. He completed two years of residency in Pediatrics at Children's Memorial Hospital in Chicago, Illinois and completed his Pediatric Residency and Fellowship training in Perinatology at Babies Hospital - the Children's Medical \& Surgical Center of New York City. At present he is in the Rustin McIntosh Fellow in Pediatrics at Babies Hospital and an Associate in ClinicalPediatrics at the Columbia Presbyterian Medical Center.

There is accumulating evidence of an increase in the activity of fetal endocrine systems at or about the time of birth, suggesting participation by the fetus in the onset of and control of labor $[2,5,10$, $11,12]$. Vasopressin, primarily an antidiuretic hormone, has the potential of influencing the onset and progress of labor by virtue of its vasocontrictor effect on uterine blood vessels $[3,13]$. Earlier studies by HoPPENSTEIN et al. [8] and CHAR D et al. [4] have documented extremely high concentrations of vasopressin in human umbilical cord blood of babies born after spontaneous vaginal delivery. While considering other factors, these authors concluded that increased fetal vasopressin secretion was due to the stress of delivery. A recent study [1], however, utilizing a chronic sheep preparation has demonstrated an increase in the fetal vasopressin secretion just before the onset of labor. This suggests the interesting possibility of a causal role of fetal vasopressin in the onset of labor. Since a similar study in human subjects is not possible, we have adopted an indirect approach to this problem. If high vasopressin concentrations in the umbilical cord blood were indeed due to stress, there might be a correlation between the magnitude of vasopressin levels and the severity of asphyxial stress. The present study is an attempt to expand the previous observation, using a different assay system, and to determine if a correlation exists between the severity of fetal asphyxia and the degree of hypervasopressinemia.

\section{Materials and methods}

Plasma vasopressin concentrations were determinẹ in four groups of infants.

I. Group A consisted of twelve "non-stressed" neonates who had peripheral venous samples collected between 48 and 72 hours of life. The total volume of the samples did not exceed $0.5 \mathrm{ml}$. 
II. Group B consisted of ten infants who were ventilated because of severe respiratory distress syndrome. These infants were felt to be maximally stressed, and had umbilical arterial samples collected between 24 and 48 hours of life. The sample volumes were similar to those in Study Group A (Mean Gestational Age 32.5 weeks).

III. Group C consisted of twenty-two spontaneously delivered infants in whom samples were separately collected from the umbilical cord artery and vein, and four infants in whom arterial and venous samples were combined. The volume of the sample varied with the length of the cord segment, but was at least $3 \mathrm{ml}$. One-half $\mathrm{ml}$ of the arterial blood was used for each acid base and $\mathrm{PO}_{2}$ determiniation (Mean Gestational Age 38 weeks).

IV. Group D consisted of 14 infants who were delivered by elective cesarean section in whom samples were collected from the umbilical cord artery and vein. Acid base and $\mathrm{PO}_{2}$ determinations were also performed on infants from this group (Mean Gestational Age 39 weeks).

Blood for each vasopressin determination was deposited into chilled vacutainer tubes containing $10.5 \mathrm{mg}$ of E.D.T.A. in a volume of $70 \mu \mathrm{l}$. The samples were centrifuged at $4^{\circ} \mathrm{C}$ and the plasma was frozen at $-20^{\circ} \mathrm{C}$ until extraction and assay within four weeks. Vasopressin was determined by radioimmunassay, details of which have been reported earlier [9]. The standard hormone used was synthetic arginine vasopressin (ScHWARZMANN). The biological activity, determined by Dr. WILBER SAWYER'slaboratory at this institution, was 250 pressor units/mg. The immunological identity of this material to the pure natural bovine preparation has previously been reported [9], the conversion factor for picograms to microunits of vasopressin being $X 0.25$.

The APGAR score for infants in Group C and D was evaluated postnatally by one individual(R.A.P.).

\section{Results}

In Group A, "non-stressed". infants, most vasopressin levels were barely detectable; the highest values did not exceed $5 \mathrm{pg} / \mathrm{ml}$.
Tab. I. Arginine vasopressin concentrations in ten infants with severe respiratory distress syndrome

\begin{tabular}{lr}
\hline Patient & $\mathrm{pg} / \mathrm{ml}$ \\
\hline 1. A & 25.0 \\
2. B & 2.5 \\
3. C & 3.5 \\
4. D & 6.3 \\
5. E & 5.0 \\
6. F & 6.3 \\
7. G & 2.5 \\
8. H & 4.0 \\
9. I & 5.6 \\
10. J & 3.6 \\
\hline
\end{tabular}

In Group B, "stressed" infants who were ventilated because of severe respiratory distress syndrome, the concentrations range from 2.5 to $25 \mathrm{pg} / \mathrm{ml}$ (Tab. I).

In infants delivered vaginally (Group $C$ ) the AVP values averaged 453.5 and ranged from 5 to $2200 \mathrm{pg} / \mathrm{ml}$ in arterial blood. More than $90 \%$ of the arterial samples had higher vasopressin concentrations than the respective venous samples ( $\mathrm{P}<0.005$ by paired $\mathrm{T}$ test). This suggests fetal origin of the hormone. Considering that the level of $25 \mathrm{pg} / \mathrm{ml}$ was the highest obtained in ten infants with severe respiratory distress who were clearly in a situation of stress, it should be noted that all but two levels among the spontaneously delivered babies were higher than this value (Tab. II).

In Group D, infants delivered by elective "Cesarean Section," all but one had umbilical arterial arginine vasopressin concentrations less than $25 \mathrm{pg} / \mathrm{ml}$ (Tab. III).

Fig. 1 graphically illustrates the lack of correlation of the umbilical arterial plasma vasopressin concentration with the umbilical arterial $\mathrm{pH}(\mathrm{r}=-.08) *$. Additionally, no correlation was evident between the vasopressin concentration and the base excess $(\mathrm{r}=+.13)^{*}$ or the infant's one minute APGAR score $(r=+.37) *$.

\section{Comment}

This study extends the observations of the previous authors $[4,8]$ which demonstrated extremely high levels of vasopressin in fetal circulation after

* Pearson Correlation Coefficient $(\mathrm{P}>.05$ for all $\mathrm{r}$ values) 
Tab. II. Arginine vasopressin concentrations in the cord blood of spontaneously delivered infants.

\begin{tabular}{|c|c|c|c|c|c|c|}
\hline Patient & $\begin{array}{l}\text { Umbilical } \\
\text { artery } \\
(\mathrm{pg} / \mathrm{ml})\end{array}$ & $\begin{array}{l}\text { Umbilical } \\
\text { vein } \\
(\mathrm{pg} / \mathrm{ml})\end{array}$ & $\begin{array}{l}\text { Umbilical } \\
\text { artery \& vein } \\
(\mathrm{pg} / \mathrm{ml})\end{array}$ & $\mathrm{pH}$ & $\begin{array}{l}\text { P } \\
\text { Base } \\
\text { Excess }\end{array}$ & $\begin{array}{l}1 \text { Min. } \\
\text { Apgar } \\
\text { Score }\end{array}$ \\
\hline $\mathbf{A}_{1}$ & 400 & 65 & & & & 6 \\
\hline$B_{1}$ & 100 & 3 & & 7.295 & -1.0 & \\
\hline $\mathrm{C}_{1}$ & 900 & 32.5 & & 7.178 & -5.0 & 8 \\
\hline$D_{1}$ & 35 & 1.5 & & 7.22 & -7.8 & 8 \\
\hline$E_{1}$ & 750 & 53 & & 7.26 & -13.0 & 7 \\
\hline$F_{1}$ & 360 & 230 & & 7.19 & -14.0 & 7 \\
\hline $\mathrm{G}_{1}$ & 135 & 80 & & 7.235 & -5.7 & 8 \\
\hline $\mathrm{H}_{1}$ & 168 & 45 & & 6.98 & -19.0 & 7 \\
\hline$I_{1}$ & 840 & 360 & & 7.304 & -6.3 & 9 \\
\hline $\mathrm{J}_{1}$ & 2,240 & 70 & & 7.29 & & 9 \\
\hline $\mathrm{K}_{1}$ & 160 & 120 & & 7.268 & -1.6 & 7 \\
\hline $\mathrm{L}_{1}$ & 60 & 30 & & & & 7 \\
\hline $\mathrm{M}_{1}$ & 220 & 240 & & & & 8 \\
\hline $\mathrm{N}_{1}$ & & & 40 & & & 8 \\
\hline $\mathrm{O}_{1}$ & & & 25 & & & 8 \\
\hline$P_{1}$ & & & 60 & 7.264 & -5.7 & 8 \\
\hline $\mathrm{Q}_{1}$ & & & 42 & 7.318 & -6.2 & 7 \\
\hline$R_{1}$ & 6 & 2.5 & & 7.216 & -4.7 & 8 \\
\hline$S_{1}$ & 4.8 & 1.3 & & 7.247 & -7.0 & 3 \\
\hline$T_{1}$ & 124 & 70 & & 7.280 & -9.0 & 8 \\
\hline $\mathrm{U}_{1}$ & 264 & 280 & & 7.190 & -14.0 & 6 \\
\hline$V_{1}$ & 312 & 4.6 & & 7.293 & -4.8 & 9 \\
\hline$W_{1}$ & 48 & 5 & & & & 8 \\
\hline$X_{1}$ & 1,600 & 900 & & 7.00 & & 8 \\
\hline$Y_{1}$ & 370 & 4.5 & & & & 7 \\
\hline $\mathrm{Z}_{1}$ & 880 & 520 & & 7.25 & -11.0 & 8 \\
\hline
\end{tabular}

Tab. III. Arginine vasopressin concentrations in the cord blood of infants delivered by elective cesarean section

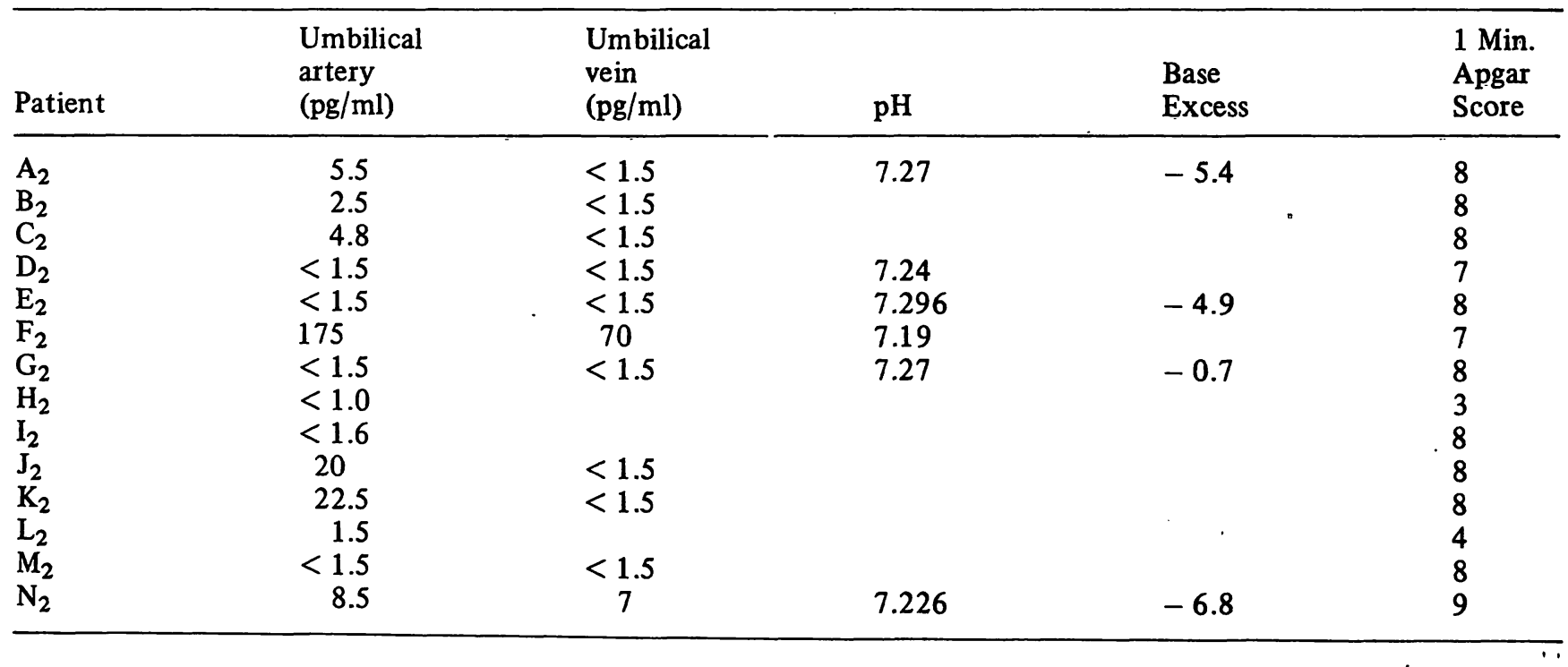

spontaneous delivery, and furthermore examines one of the possible mechanisms. Levels in cord blood from such infants greatly exceeded those from both normal, non-stressed neonates, and premature infants stressed postnatally with severe repiratory distress syndrome. The fetal neurohypophysis, on the other hand, appears to be remarkably quiescent in the absence of labor, i.e., 


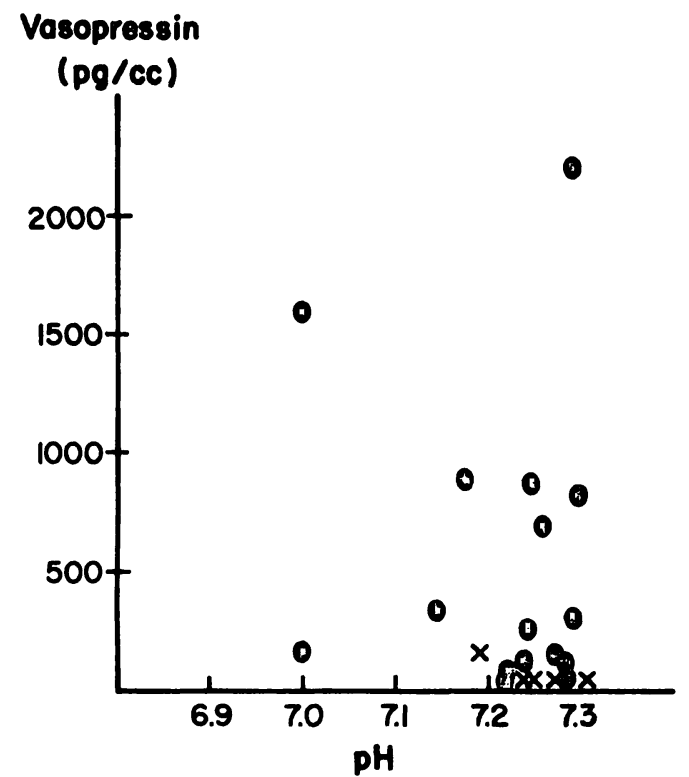

Fig. 1. The noncorrelation of the umbilical arterial plasma vasopressin concentration with umbilical arterial $\mathrm{pH}$. $()=$. Spontaneous vaginal delivery,$(x)=$ Cesarean section.

cesarean section, suggesting the possibility that the increase in vasopressin concentration may be related to labor. The increase may represent either a non-specific response of the fetus to the stress of vaginal delivery, or a primary event preceding or related to parturition. Although there are a number of stresses to which the infant in utero may be subjected, inadequate placental exchange of oxygen and carbon dioxide is the most severe and represents the most frequent occurrence.
Despite extreme variation, between 5-2200 pg/ml, we were unable to demonstrate a correlation between the umbilical arterial vasopressin concentration, and the simultaneously determined $\mathrm{pH}$, base excess and one minute APGAR score. These data strengthen the inference that the increase in plasma vasopressin is not solely related to asphyxial stress. HopPENSTEIN et al. [8] observed that the newborn infants' increase in blood vasopressin concentration in response to surgical stress was significantly less than that of olderinfants. Although the number of determination were few ( 5 infants), this may also mean that during the neonatal period, the human posterior pituitary is less capable of releasing vasopressin in response to stress. Vasopressin has long been regarded as a stress related hormone [6]. Contrary to this concept, BRENNAN et al. [2], using a radioimmunoassay similar to ours, have very recently reported that certain forms of stress, which were severe enough to activate the pituitary adrenal axis in rats, failed to release vasopressin.

From human cord blood measurements alone, it is not possible to determine the time sequence of excessive vasopressin release in relation to the onset and progress of spontaneous labor. The increased concentration of AVP in the umbilical artery following spontaneous delivery suggests that there might be a role for the fetus in the initiation of labor.

\section{Summary}

Marked elevations in the vasopressin concentrations in human umbilical cord blood have been reported previously $[4,8]$. This could either be a part of generalized increase in the activity of fetal endocrine system at the time of birth, a phenomenon that has led to the concept of fetal participation in the onset of labor, or simply due to the stress of delivery. The present study is an attempt to examine the later possibility. Plasma vasopressin was determined by radioimmunoassay [9] in separately collected arterial and venous blood from the umbilical cords of 24 babies spontaneously delivered and 14 babies born after Caesarian Section in the absence of labor. Arterial acid-base determinations were done in each case. The Apgar Score was evaluated by one individual. In order to obtain a general idea of circulating concentration of

this hormone in the neonatal period, vasopressin concentrations were determined in the systemic venous blood of 12 normal and 10 stressed babies. Vasopressin concentrations in the umbilical arterial blood of babies born after spontaneous delivery were remarkably high, as compared to all the other groups. Despite a wide range, between $5-2200 \mathrm{pg} / \mathrm{ml}$, there was no correlation between the magnitude of vasopressin elevation and the severity of fetal asphyxia (Fig. 1). The present finding in part, confirms and expands previously observed increased vasopressin levels in the cord blood after spontaneous vaginal delivery. In addition, a lack of correlation between fetal asphyxia and the vasopressin levels suggests that these high levels may not be related to this form of stress.

Keywords: Fetal neurophypophysis, parturition, stress, vasopressin. 


\section{Zusammenfassung}

Hohe Vasopressin-Konzentrationen im menschlichen Nabelschnurblut - mangelnde Korrelation mit Streßfaktoren

Kürzlich wurde über deutlich erhöhte Vasopressin-Konzentrationen im menschlichen Nabelschnurblut berichtet [4, 8]. Dies könnte entweder Teil einer generalisierten Aktivitätssteigerung des fetalen Endokriniums zum Zeitpunkt der Geburt sein - ein Phänomen, das zu der Vorstellung einer fetalen Beteiligung beim Wehenbeginn geführt hat - oder es könnte lediglich auf den Geburtsstreß zurückgeführt werden. Die vorliegende Arbeit macht den Versuch, die letztgenannte Möglichkeit zu überprüfen. Im separat gewonnenen Nabelschnurblut aus Arterie und Vene von 24 Neugeborenen, die spontan geboren und 14 Neonaten, die nach primärer Sectio caesarea ohne vorausgegangene Wehentätigkeit zur Welt gekommen worden waren, wurde Plasma-Vasopressin mit Hilfe eines Radioimmunoassays [9] bestimmt. In jedem Fall wurden Bestimmungen der Parameter des Säurebasenhaushaltes im arteriellen Blut durchgefüht't. Die Bewertungen nach APGAR sind von einer Person durchgeführt worden. Um einen Anhalt zu haben hinsichtlich der zirkulierenden Hormonkonzentrationen in der Neonatalperiode, wurden bei 12 normalen und 10 deprimierten Neugeborenen Vasopressinkonzentrationen im venösen Blut bestimmt. Die Vasopressinkonzentrationen im Blut der Nabelarterie von spontan geborenen Kindern waren erstaunlich hoch im Vergleich mit allen anderen Gruppen. Ungeachtet der großen Streubreite, die zwischen 5 und $2200 \mathrm{pg} / \mathrm{ml}$ lag, bestand keine Korrelation zwischen der Höhe des Vasopressinspiegels und dem Schweregrad der fetalen Asphyxie (Fig. 1). Die vorliegenden Befunde bestätigen und erweitern teilweise die kürzlich gemachte Beobachtung von erhöhten Vasopressinspiegeln im Nabelschnurblut nach vaginaler Spontangeburt. Zusätzlich läßt der Mangel an Korrelation zwischen fetaler Asphyxie und Vasopressinspiegel vermuten, daß die hohen Hormongehalte mit dieser Art von Streß nicht assoziiert sind.

Schlüsselwörter: Fet, Geburt, Neurohypophyse, Streß, Vasopressin

Résumé

Concentrations élevées de vasopressine dans le sang ombilical humain - Manque de correlation avec le stress Des hausses sensibles des concentrations de vasopressine dans le sang ombilical humain ont déjà été mentionnées dans la littérature $[4,8]$. Ceci pourrait résulter soit d'une intensification généralisée de l'activité du système endocrinal foetal au moment de la naissance, un phénomène qui est à l'origine du concept de la participation foetale au déclenchement du travail, soi du stress de l'accouchement. L'article présent parte sur l'examen de cette seconde possibilité. La vasopressine du plasma a été définie par essai radio-immunologique [9] sur des échantillons prélevés isolément dans le sang artériel et veineux du cordon ombilical de 24 bébés nés après accouchement spontané et de 14 bébés nés après section césarienne consécutive à une absence de travail. Des définitions acidobaxiques artérielles ont étéeffectuées dans chaque cas. Afin d'obtenir une idée générale de la concentration curculatoire de cette hormone en période néonatale, on a établi les concentrations de vasopressine dans le sang veineux systémique de 12 bébés normaux et de 10 sous stress. Les concentrations de vasopressine du sang ombilical artériel de bébés nés après accouchement spontané étaient extrêmement élevées par rapport à celles des autres groupes. En dépit d'une grande marge de variabilité, entre 5 et $2200 \mathrm{pg} / \mathrm{ml}$, on n'a observé aucune corrélation entre l'amplitude de la hạusse de vasopressine et la gravité d'asphyxie foetale (Fig. 1). Les résultats présents, d'une part, confirment et développent les observations antérieures des hausses de vasopressine dans le sang ombilical aṕrès des accouchements vaginaux spontanés. De plus, le manque de corrélation entre l'asphyxie foetale et les taux de vasopressine donne à penser que ces taux élevés n'ont peut-être aucune relation avec cette forme de stress.

Mots-clés: Neurohypophyse foetale, parturition, stress, vasopressine.

\section{Bibliography}

[1] AleXANDER, D. P., R. A. BASHONE, H. G. BRITTON, M. L. FORSLING: Maternal and fetal arginine vasopressin in the chronically catheterized sheep. Biol. Neonate 25 (1974) 242

[2] BRENNAN, T. C., R. L. SHELTON, G. L. ROBERTSON: Effect of stress on plasma vasopressin and corticosterone in rats. Clin. Res. 28 (1975) $234 \mathrm{~A}$
[3] BROTANE K, V. C., C.H.HENDRICKS,T.TOSHIDA: Importance of changes in uterine blood flow of labor. Amer. J. Obstet. Gynec. 105 (1969) 535

[4] CHARD, T., C. N. HUDSON, C. R. W. EDWARDS, N. R. H. BOYD: Release of oxytocin and vasopressin by the human fetus during labor. Nature 234 (1971) 352 
[5] DROST, M., L. W. HOLM: Prolonged gestation in ewes after foetal adrenalectomy.J. Endocr. 40 (1968) 293

[6] GINSBERG, M.: Production, release, transportation and elimination of the neurohypophysial hormones. In: BERDE, B., Neurohypophysial hormones and similar poly peptides. Springer-Verlag, New York 1968

17] HOLM, L. W.: The gestation period of mamals. In: ROWLANDS, I. W.: Comparative biology of reproduction in mamals. Academic Press, New York 1966

[9] HUSAIN, M. K., N. FERNANDO, M. SHAPRIO, A. KAGAN, S. M. GLICK: Radioimmunoassay of arginine vasopressin in human plasma. J. Clin. Endocrinol. Metab. 37 (1973) 616
[10] LIGginS, G. C., P. C. KENNEDY, L. W. HOLM: Failure of initiation of parturition after electrocoagulation of the pituitary of the fetal lamb. Amer. J. Obstet. Gynec. 98 (1967) 1080

[11] MURPHY, B. E. P.: Does human fetal adrenal play a role in parturition. Amer. J. Obstet. Gynec. 115 (1973) 521

[12] PERRY, J. S.: Control of parturition: Eleventh symposium of the society for the study of fertility. J. Rep. and Fertility, Suppl. 16 (1972)

[13] SOMLYO, A. P., A. V. SOMLYO: Vascular smooth muscle II: Pharmacology of normal and hypertensive vessels. Pharmacological Reviews 22 (1970) 249

Received June 10, 1976. Accepted September 30, 1976.

Dr. Richard A. Polin

Babies Hospital

3975 Broadway

New York, N.Y.10032/USA 